\title{
Performance Appraisal with Reference To Loganathan Interior Company
}

\author{
S. Praveen Kumar, Karthikeyan P, D. Raviteja
}

\begin{abstract}
Execution examination is "the way toward assessing the presentation and capability of the representatives as far as the organization including for advancement, giving budgetary prizes and other situation, choice activities which require differential treatment among the individuals from a gathering as recognized from activities influencing all individuals similarly." Execution examination is the efficient assessment of individual regarding his/her presentation at work and his/her potential for advancement. Execution evaluation is the precise portrayal of representative's activity pertinent quality and shortcoming. The object is to discover how well the worker is playing out his activity and set up an arrangement of progress. Execution evaluation is masterminded occasionally as per a positive arrangement. Execution examination isn't work assessment. Execution evaluation alludes to how well somebody is getting along the allocated activity.
\end{abstract}

Keywords: Financial rewards, Performance appraisal, Organizational performance

\section{INTRODUCTION}

Execution examination is a basic and inevitable administrative action. Examination is fundamental for immensely significant choices identifying with individuals, for example, position and advancement, compensation and reward, preparing and improvement, just as long haul labor arranging and association improvement[1],[3],[5]. As of late, endeavors have been made to utilize examination frameworks for inspiration, for additional successful correspondence, for reinforcing unrivaled subordinate connections, for objective setting and work arranging and for improving the absolute execution of the association. In any case, regardless of its significance, uneasiness about evaluation has been a long-standing component of the executives[2 ],[4],[6]. There is no uncertainty during the previous three decades, numerous advancements have occurred and numerous developments, have been made in administrative examination framework. In any case, numerous issues stay uncertain. Accessible writing regarding the matter uncovers than even in the western nations, where orderly evaluations have been broadly practice over an any longer period than in India and where a considerable measure of exact just as hypothetical research on the important issues has been directed, genuine questions keep

Revised Manuscript Received on July 22, 2019.

Dr. S. Praveen Kumar, Department of MBA, Bharath Institute of Higher Education and Research, Chennai, India. Email: praveenkumar.mba@bharathuniv.ac.in

Karthikeyan P, Department of MBA, Bharath Institute of Higher Education and Research, Chennai, India. Email: karthikeyanp23@gmail.com

D. Raviteja, Department of MBA, Bharath Institute of Higher Education and Research, Chennai, India.. Email: raviteja44@gmail.com on persevering about different parts of examination[7],[ 9],[11].

In this current circumstance execution examination become significant angle for the development and improvement of the association [8],[10],[12]. As drinks businesses are enlisting their representatives everyday and giving the best compensations and offices, the understudy analyst thought to do her study in Analyzing of execution in reference to Longanathan (Chennai).

Chennai to think about the reality in that association. The understudy scientist again attempted to think about the hypotheses accessible in the books, diaries and so forth with the viable usage in that organization[13], [15],[17]. She uncovered the circumstance and found that the evaluation framework received by the organization was great and acceptable among every one of the workers. Further she cited focuses and proposed few points for the improvement of the workers.

\section{OBJECTIVES}

To think about and dissect diverse execution examination plans given by the HCCB PVT.LTD.

2. To contemplate the current yearly presentation examination framework in HCCB PVT.LTD. 3. To contemplate the proficiency of the framework and generally speaking rating during a year ago[14],[16], [18] .

4. To ponder the relational and group association with companions, bosses and subordinates.

5. To think about the presentation input and directing framework for representatives in HCCB PVT.LTD.

6.To break down the worker frame of mind towards the present evaluation framework.

7.To improve work fulfillment and self realization of representatives by empowering, and helping each worker to understand his or her maximum capacity[19],[21],[23].

\section{A. Significance}

This examination concentrated on the impact of execution evaluation quality on worker execution the instance of The expressed beneath are a portion of the advantages that are drawn from this investigation[20],[22],[24]

It causes the association to stick point the significant difficulties that exist presently and take therapeutic activities for reasonable positive outcomes. .

] It serves us a reference material for both human asset Practitioners and academicians. 
THE COMPANY will legitimately profit as the discoveries when actualized will result in the improvement of execution evaluation in this manner improved execution.

$\square$ All separate associations can utilize the consequence of this investigation as a seat mark in estimating their exhibition against the measurements utilized in this examination and reassesses the current execution evaluation rehearses. [25],[27],[29]

$\square$ It starts different specialists who may be keen on seeking after research in a similar region.

\section{RESULTS}

1. It saw that $86 \%$ of the respondents opinioned on the exhibition evaluation framework presence in the association, where as $14 \%$ of the respondents opinioned on the examination framework non presence. In this way lion's share are thinking about the presence of evaluation framework.

2. It saw that $57.1 \%$ opinioned on the inclination to peers, $28.6 \%$ opinioned that, they favor execution audit council and $14.3 \%$ opinioned that, they lean toward others. Henceforth it can presume that lion's share are inclining toward the companion on evaluation[26],[28],[30].

3. It can saw that $78.5 \%$ opinioned on the exhibition evaluation was done at the work environment and $21.5 \%$ opinioned that, the presentation examination was done at other spot in the association.

4. It can broke down that $42.8 \%$ opinioned were completely mindful of the presentation evaluation framework, $28.6 \%$ opinioned that, they were mostly mindful opinioned that, they were not in the least mindful of the presentation evaluation framework. Subsequently it can said that dominant part are having mindfulness.

\section{DISCUSSIONS}

1. Just couple of respondents opinioned that the examination components are brilliant. So the association needs to think about great variables for evaluation.

2. The association need to consider 360 degree examination framework since they lean toward additional to the friends.

3. For each association the familiarity with execution examination is significant. So the association needs to make $100 \%$ mindfulness about execution examination framework.

4. The exhibition examination ought to be led dependent on the very much characterized target.

5. Occupation investigation is one of the overwhelming components for evaluation so the association need to give more significance for employment examination while leading examination.

6. The association needs to build proficiency of framework by setting up the great measures for execution examination.

7. The criticism assumes a noteworthy job during the time spent correspondence between the prevalent and the of the presentation evaluation framework and $28.6 \%$

subordinate. With the goal that the association need to give quick criticism to its representatives.

\section{V.CONCLUSION}

At last I should arrive at my derivation in this point execution assessment structure. It is one of the essential issues where delegates expect incredible results which lead to high satisfaction. This assessment even goes about as an analysis system, which accept an imperative occupation in the improvement of the relationship through annihilating the correspondence deterrents between the unparalleled and the subordinate. In the current circumstance structure raises the relationship with rich proficiency. A conventional plan of execution assessment turns out through perfect rating of the laborers and their analysis for the given rating. The system should work so the things to be done through the people. HCCBPL included an obvious position in the business in its things and it has been achieving its goals regardless of obstacles went up against and stayed at a nice position with a perfect vision[31],[33]. The delegates of HCCBPL are content with the course of action of assessment sought after there, in perspective on its stress and thought towards the laborers by the organization. Finally I wrap up my subject "execution assessment ", the work and the related issues were certainly changed when diverged from the past. Execution assessment is an unstable issue since it not evaluation for the achievers yet also trains and cautions to the low supporters. Everything done by the affiliation should be recognized the agents and even make the see that it is practiced for the incredible motivation behind specialists. This factor is dire for any relationship to achieve its objectives.

\section{REFERENCES}

1) BharthVajan R., Ramachandran S.,Psychographic dimensions of training,2016,International Journal of Pharmacy and Technology,V-8,I-4,P-23727-23729

2) Balakrishnan P., Bharthvajan R.,A study on human resource planning in hospitals in Chennai City,2014,International Journal of Applied Engineering Research,V-9,I-22,P-7503-7507

3) Priyadarsini P., Bharthvajan R.,Role of emotional intelligence training programme in reducing the stress of the nurses,2014,International Journal of Applied Engineering Research,V-9,I-22,P-7411-7421

4) Kerinab Beenu G., Bharthvajan R.,Empirical analysis on the cosmetic buying behavior of young women in South India,2014,International Journal of Applied Engineering Research,V-9,I-22,P-7361-7366

5) Balakrishnan P., Bharthvajan R.,Whistling in the wind,2014,International Journal of Applied Engineering Research,V-9,I-22,P-7586-7593

6) Krishnan B., Peter M.,Health hazards of Indian Bpo employee-an alarming issue,2014,International Journal of Applied Engineering Research,V-9,I-22,P-7336-7341

7) Kerinab Beenu G.H., Peter M.,Role of insurance in economic development,2014,International Journal of Applied Engineering Research,V-9,I-22,P-7532-7539

8) Balakrishnan P., Peter M., Priyadarsini P.,Efficiency of safety measures for wellbeing of employees in manufacturing industry,2014,International Journal of Applied Engineering Research,V-9,I-22,P-7376-7382

9) Anbarasi M., Praveen Kumar S.,Online sales promotions of herbal products and its effectiveness towards tanisha.com,2019, Indian Journal of Public Health Research and Development,V-10,I-1,P-195-200

10) Anbarasi M., Praveen Kumar S.,Various online marketing and promotions strategies to improve the validation towards the organic products in the pharmaceutical sectors,2019,Indian Journal of Public Health Research and Development,V-10,I-1,P-263-269 
11) Loganathan R., Praveen Kumar S.,Grievance handling a key factor for solving issues of employees in an organization,2014,International Journal of Applied Engineering Research,V-9,I-22,P-7483-7491

12) Loganathan R., Praveen Kumar S.,Study on preference of private label brands in super and Hypermarkets,2014,International Journal of Applied Engineering Research,V-9,I-22,P-7327-7335

13) Smitha M., Praveen Kumar S.,Understanding stress and its managementamong the nurses in Chennai city,2014,International Journal of Applied Engineering Research,V-9,I-22,P-7560-7565

14) Kerinab Beenu G.H., Praveen Kumar S.,A study on the investment behavior of Chennai investors in mutual fund schemes,2014,International Journal of Applied Engineering Research,V-9,I-22,P-7520-7525

15) Loganathan R., Praveen Kumar S.,Retention strategies key for organizational productivity,2014,International Journal of Applied Engineering Research,V-9,I-22,P-7443-7447

16) Pavithra J., Ganesan M., Brindha G.,State wise analysis of microfinance sector in India,2016,International Journal of Pharmacy and Technology,V-8,I-4,P-23417-23432

17) Pavithra J., Ganesan M.,A comparative study on microfinance in India and abroad,2016,International Journal of Applied Business and Economic Research,V-14,I-8,P-5471-5476

18) Pavithra J., Ganesan M.,A study on awareness and impact of micro-financial schemes,2016,International Journal of Applied Business and Economic Research,V-14,I-8,P-5449-5460

19) Senthilmurugan P., Pavithra J.,Consumer preference towards organised retailing with reference to Big Bazaar,2014,International Journal of Applied Engineering Research,V-9,I-22,P-7469-7475

20) Senthilmurugan P., Pavithra J.,Implication of social media marketing in growing healthcare industry,2014,International Journal of Applied Engineering Research,V-9,I-22,P-7448-7456

21) Loganathan R., Pavithra J.,Consumer perception towards private label brand over other brands in super markets and hypermarkets,2014,International Journal of Applied Engineering Research,V-9,I-22,P-7355-7360

22) Kerinab Beenu G., Pavithra J.,Tradeâ€"off between liquidity and profitability in logistics industry,2014,International Journal of Applied Engineering Research,V-9,I-22,P-7398-7401

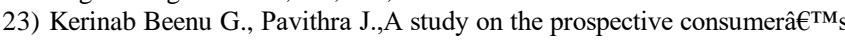
perception towards utility cars in Chennai city,2014,International Journal of Applied Engineering Research,V-9,I-22,P-7526-7531

24) Pavithra J., Dilli Babu P., Ambuli T.V.,A study on budgetary control at Maruti Service Masters, Chennai,2014,International Journal of Applied Business and Economic Research,V-12,I-2,P-151-161

25) Pavithra J., Dilli Babu P., Ambuli T.V.,A study on customer satisfaction of retro Garments Pvt Ltd, Chennai,2014,International Journal of Applied Business and Economic Research,V-12,I-2,P-381-391

26) Kerinab Beenu G.H., Pavithra J., Senthilmurugan P.,A study on the influence of promotional activities for TATA ARIA among consumers in Chennai,2014,International Journal of Applied Engineering Research,V-9,I-22,P-7572-7578

27) Vijayaragavan S.P.,An investigative expert that's general FBG sensors,International Journal of Mechanical Engineering and Technology,V-8,I-8,PP-1500-1505,Y-2017

28) Vijayaragavan S.P.,Equalization routing protocol for Wi-Fi sensor strategy,International Journal of Mechanical Engineering and Technology,V-8,I-8,PP-1662-1666,Y-2017

29) Karthik B., Kiran Kumar T.V.U., Vijayaragavan P., Bharath Kumaran E.,Design of a digital PLL using 0.35 $\hat{\mathrm{I}}^{1 / 4 \mathrm{~m}}$ CMOS technology,Middle East Journal of Scientific Research,V-18,I-12,PP-1803-1806,Y-2013

30) Kanniga E., Selvaramarathnam K., Sundararajan M.,Kandigital bike operating system,Middle - East Journal of Scientific Research,V

31) Jasmin M., Vigneshwaran T., Beulah Hemalatha S.,Design of power aware on chip embedded memory based FSM encoding in FPGA,International Journal of Applied Engineering Research,V-10,I-2,PP-4487-4496,Y-2015

32) Jasmin M.,Optimization techniques for low power VLSI circuits,Middle East Journal of Scientific Research,V-20,I-9,PP-1082-1087,Y-2014

33) Jasmin M., Vigneswaran T.,Fuzzy controller for error control of on - Chip communication,2017 International Conference on Algorithms, Methodology, Models and Applications in Emerging Technologies, ICAMMAET 2017,V-2017-January,I-,PP-1-5,Y-2017

\section{AUTHORS PROFILE}

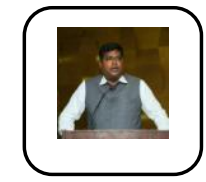

Dr. S. Praveen Kumar Professor, Department of MBA, Bharath Institute of Higher Education and Research, Chennai, India.

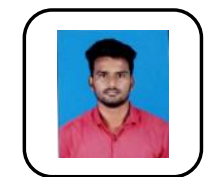

Karthikeyan P Student, Department of MBA, Bharath Institute of Higher Education and Research, Chennai, India.

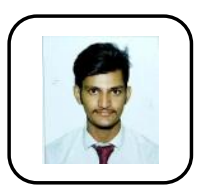

D. Raviteja Student, Department of MBA, Bharath Institute of Higher Education and Research, Chennai, India. 